Editorial

\title{
Letter from the Editors: Special Forum on "Research Methods in International Business"
}

\author{
Roberta Aguzzoli, Guest Editor ${ }^{1}$ a, Emma Gardner, Guest Editor ${ }^{2}$, William Newburry, Associate Editor ${ }^{3}$ b \\ 1 Durham University, UK, 2 University of Birmingham, UK, ${ }^{3}$ Florida International University, USA \\ Keywords: research methods, qualitative comparative analysis, social identity theory, value chain, covid-19 \\ https://doi.org/10.46697/001c.24425
}

\section{AIB Insights}

Vol. 21, Issue 2, 2021

\begin{abstract}
This issue, developed in cooperation with the Academy of International Business Research Methods Shared Interest Group, explores the importance of utilizing sound research methods when studying international business phenomena. In addition to featuring two research methods-focused articles, it also presents articles on social identity theory in the age of identity politics, Tik-tok and the splinternet, and the different value chain requirements for medical devises in the COVID-19 era.
\end{abstract}

Since the 1970s, the importance of sound and diverse methodology as a good practice has been a central topic in the Academy of International Business (AIB) community (e.g., Dymsza, 1979; Dymsza \& Vambery, 1977; Vambery, 1978). Fast forward to the current time, and we see a growing public consciousness regarding the quality and the source of information received and digested - i.e., fake news. This translates to what we consider as rigor and validity, and more recently, the discussion on research transparency.

The study of international business (IB) involves objective topics such as foreign direct investment (FDI), which can be captured by quantitative data, but also accounts for culture, consumer behaviour, and politics, areas which are difficult to quantify, predict and measure. The study of cultural differences, for example, ideally incorporates integrative methodologies that assess "a mosaic of different realities" (Saukko, 2005: 354). International business, at its core, is an interdisciplinary field. We are social scientists, organizational psychologists, anthropologists, economists and more. The foundations of our community are embedded within a plethora of disciplines, which bring rich insights and strategies for 'doing' research.

The AIB community, from its beginning, has recognized the importance of IB as an interdisciplinary field and encouraged research that demonstrates this trait (e.g., Dymsza, 1979). However, over time, the IB field, or at least its more elite research, has become somewhat standardized, adhering to legitimized (publishable) methods and techniques, mainly where statistical models could validate and quantify the expected rigor and validity. This has resulted in limited variation and innovation within a variety of methods (Nielsen et al., 2020), but it is up to the community to address this, and for gatekeepers to provide conduits for re- search that veers off a recipe. It is crucial to recognize that each method, conducted appropriately, has its own rigor. However, it is important for researchers to openly discuss the methodological problems faced and how they were managed when reporting on research.

We need to explore ways to bring methods to the center of the discussion. The first thing to do is to acknowledge the importance of the different methods available and how diversity enhances discoveries. Although there were several initiatives to strengthen diversity in IB research, the field remains embedded in quantitative research - from the teaching at universities to the publications appearing in top journals (Welch \& Piekkari, 2017). While it is important that universities still train their students and researchers on strategies and formulas for publishing in top journals, such training reproduces and perpetuates a formula that seems to fit some academics' expectations of what is quality research (Alvesson \& Gabriel, 2013), with a strong focus on quantitative skills and a subsequent lack of attention to qualitative methods (Cuervo-Cazurra, Andersson, Brannen, Nielsen, \& Reuber, 2016). As many PhDs leave academia, business schools are essentially training grounds for the corporate world. Thus, imparting knowledge and skills regarding responsible research methods, whether this relates to data collection or analysis, is key. Fundamentally, we need to train all students (not just doctoral!) to think critically about the data already out there, and which is consumed by organizations.

We need to also rethink the templates deployed in academic publishing within the field of IB. The contributions of papers appear to be intrinsically linked to how well methodology fits certain standards. By following guidelines and standardized patterns, we may be limiting creativity and the opportunity for new methods to emerge (Alvesson \&

\footnotetext{
a Editor names are listed in alphabetic order.

b Contact: newburry@fiu.edu
} 
Gabriel, 2013). Within IB, and academia more widely, we hear of the need to address the grand challenges (e.g., Buckley, 2020; Eden, 2020). But, to do this, we need to adopt appropriate research designs and methods. The field needs to step away from doing what is comfortable to doing what is necessary. This, however, requires the community as a whole to recognize this issue; as each member has a part to play in enabling methodological variety. Reviewers are essentially the gatekeepers and the decision-makers in the publication process, with a large degree of influence in accepting and rejecting papers, and even perpetuating the current mind-set of what is 'good' research, and legitimizing the publication decisions made (Alvesson \& Gabriel, 2013). While the peer review process is central to academic integrity, we need reviewers capable of reviewing a wider variety of research methods. How can new or less popular methods populate journal pages if gatekeepers are unwilling or unable to 'authorize' alternative research designs and methodologies? It could be argued that this reinforces the need for greater breadth of training for junior scholars.

Comprehensive training for researchers along with the use of different and comprehensive methodologies can help us to work on meaningful topics, to be close to society and business and help to answer their struggles in the IB field. Most of IB is done by SMEs, and still, there are very few studies that can fit their demands (Dabić et al., 2020; Hilmersson \& Johanson, 2016). As institutional frameworks of performance assessment adapt to focus on external engagement and impact, the IB community is becoming more cognizant of conducting research that has meaning beyond academia. Ultimately for our research to be relevant, it needs to be transferable to practice, to policy, and ultimately to society. In turn, this highlights a need for greater collaboration between academia, industry and policymakers, to ensure that synergies can be achieved.

We invite the IB community to reflect on those questions that have been largely taken for granted. The AIB's recognition of the importance of research methods is demonstrated by the Research Methods Shared Interest Group (RM-SIG). The AIB RM-SIG aims to provide AIB members with a forum for researchers to engage in discussion of research methodologies, advance the quality, diversity and understanding of research methodologies, and stimulate innovation in the use of new methodologies among AIB members.

More specifically, the objectives of the Research Methods Shared Interest Group are to:

- Provide AIB members with a worldwide forum for scholarly engagement about research methodologies;

- Advance the quality, diversity and understanding of research methodologies in the AIB;

- Provide a repository of knowledge for AIB members on the range of, and trends in, research methodologies;

- Stimulate innovation in research methodologies and promote the use of novel methodologies;

- Organize doctoral training and professional development opportunities for AIB members on research methodologies at conferences such as the AIB Annual Meeting and through events hosted at different universities;

- Alongside the AIB, assist in building the research ca- pacity of new researchers and emerging countries and regions.

This issue was developed by the AIB Research Methods SIG, working with AIB Insights Associate Editor William Newburry. Two RM-SIG members, Roberta Aguzzoli and Emma Gardner, served as Guest Editors.

Finally, before overviewing the specific articles in this issue, we would like to highlight some of the recent commentaries and articles in one of our sister publications, the Journal of International Business Studies, which is the flagship publication for the international business field. These articles provide excellent guidance in addressing many research methodology issues that can help overcome the issues identified above. The topics and authors are listed below with the full citations contained within the reference section.

- Dealing with dynamic endogeneity in international business research by Jiatao $\mathrm{Li}$, Haoyuan Ding, Yichuan $\mathrm{Hu}$, and Guoguang Wan (2021)

- The anatomy of an award-winning meta-analysis: Recommendations for authors, reviewers, and readers of meta-analytic reviews by Piers Steel, Sjoerd Beugelsdijk, and Herman Aguinis (2021)

- A new approach to data access and research transparency (DART) by Sjoerd Beugelsdijk, Arjen van Witteloostuijn and Klaus E. Meyer (2020)

- Fifty years of methodological trends in JIBS: Why future IB research needs more triangulation by Bo Bernhard Nielsen, Catherine Welch, Agnieszka Chidlow, Stewart Robert Miller, Roberta Aguzzoli, Emma Gardner, Maria Karafyllia and Diletta Pegoraro. (2020)

- The contributions of qualitative comparative analysis (QCA) to international business research by Stav Fainshmidt, Michael A. Witt, Ruth V. Aguilera and Alain Verbeke (2020)

- Misconceptions about multicollinearity in international business research: Identification, consequences, and remedies by Thomas Lindner, Jonas Puck and Alain Verbeke (2020)

- Science's reproducibility and replicability crisis: International business is not immune by Herman Aguinis, Wayne F. Cascio and Ravi S. Ramani (2017)

- What's in a p? Reassessing best practices for conducting and reporting hypothesis-testing research by Klaus E. Meyer, Arjen van Witteloostuijn and Sjoerd Beugelsdijk (2017)

- Can I trust your findings? Ruling out alternative explanations in international business research by Alvaro Cuervo-Cazurra, Ulf Andersson, Mary Yoko Brannen, Bo Bernhard Nielsen and A. Rebecca Reuber (2016)

- Experimental designs in international business research by Mary Zellmer-Bruhn, Paula Caligiuri and David C. Thomas (2016)

Proceeding to the content of this issue, we start with two articles focused on research methods. This first article, coauthored by Stewart R. Miller, Catherine Welch, Agnieszka Chidlow, Bo Bernard Nielsen, Diletta Pegoraro and Maria Karafyllia, is titled "The Adoption Challenge: An Analysis 
of Research Methods in JIBS.” In this study, the authors use the concepts of translational distance and complexity distance to discuss the challenges related to the adoption of research methods in JIBS through the analysis of three analytical techniques and data collection approaches: (1) Heckman models, (2) ethnographic studies, and (3) data collection equivalence procedures in survey-based research. The authors found that progress has been made to reduce translational and complexity distance for analytical techniques. The authors also raise concerns that remain for data collection equivalence and ethnography as IB scholars in those areas appear to be using increasingly advanced analytical techniques on less credible data.

The second article, by Stav Fainshmidt, Kira Haensel and Daniel Andrews, is titled "Bringing Research Closer to Reality: Configurational Analysis and Practical International Business Research." In this paper, Dr. Fainshmidt and colleagues point out that in order for IB research to generate a realistic understanding of cross-border and comparative phenomena, scholars need to employ research designs and analytical techniques that, to the extent possible, approximate the complex reality of doing business across borders or in distinct contexts. For that, the authors suggest that Qualitative Comparative Analysis (QCA) is a tool IB researchers can use to better understand IB phenomena characterized by causal complexity. The authors briefly review the core tenets of QCA, provide an example of how it can be applied to study practical IB issues, and offer recommendations for adopting QCA by researchers situated at the intersection of IB practice and scholarship.

In addition to the two research methods articles, this issue also features three eclectic articles. The journal welcomes additional individual submissions such as these excellent three examples.

Among these, Matevz (Matt) Raskovic presents the article "(Social) Identity Theory in an Era of Identity Politics: Theory and Practice.” Dr. Raskovic examines social identity theory (SIT) in an effort to assist IB scholars to go beyond applying it to just in-group/out-group behaviour. He claims that SIT helps managers to address increasing relevance of identity politics, uncertainty and divisiveness. The article overviews the current use of SIT by IB scholars, identifies potential areas of application and provides theoretical and managerial recommendations for the use of SIT.

Next, Maximilian Stallkamp authors "TikTok: International Business and the Splinternet." The internet is evolving from a globally connected and lightly regulated network to a 'splinternet' governed by diverging national policies. Governments are effectively re-creating national borders in digital space by asserting their authority over areas such as data protection, taxation, censorship, and national security. This increasing fragmentation of the internet creates new challenges for companies that use the internet to offer digital products and services (such as apps) internationally. Rather than addressing global markets more or less by default, Dr. Stallkamp suggests that these digital firms must make strategic choices with respect to foreign market selection, entry modes, local adaptation, and stakeholder management.

Finally, complimenting our recent special issue on the topic of COVID-19 and international business (2020, Vol. 20, Issue 3, see Mezias \& Newburry (2020) for an overview), Lilac Nachum presents "Global Pandemics and the Economics of Value Chains: COVID-19 and the Production of Medical Devices." This article highlights that the rationale for organization of the production of medical devices differs from that of most other products. Dr. Nachum points out that the conflict between the benefits of global integration and the imperatives of secured and speedy supply favor different production modes for these devices, and suggests that value chains of different geographic scales are said to be suitable for different medical devices. She develops a model based on the trade offs between global integration and speed in order to assist policy makers in designing differentiated policies towards different medical devices and to encourage scholars to rethink the determinants of supply chains structures across industries.

Overall, we hope that you enjoy this issue, which is our fourth peer reviewed issue. Having completed a first full year using a peer review process within our new journal system, we believe the journal has progressed significantly and hope you do too! Please continue to submit your applied international business work to AIB Insights! 


\section{REFERENCES}

Aguinis, H., Cascio, W. F., \& Ramani, R. S. 2017. Science's reproducibility and replicability crisis: International business is not immune. Journal of International Business Studies, 48: 653-663.

Alvesson, M., \& Gabriel, Y. 2013. Beyond formulaic research: In praise of greater diversity in organizational research and publications. Academy of Management Learning \& Education, 12(2): 245-263.

Beugelsdijk, S., van Witteloostuijn, A., \& Meyer, K. E. 2020. A new approach to data access and research transparency (DART). Journal of International Business Studies, 51: 887-905.

Buckley, P. J. 2020. International business research and the World Investment Report: "big questions" and grand challenges. AIB Insights, 20(4). https://doi.org/10.46697/001c.17987.

Cuervo-Cazurra, A., Andersson, U., Brannen, M. Y., Nielsen, B. B., \& Reuber, A. R. 2016. From the Editors: Can I trust your findings? Ruling out alternative explanations in international business research. Journal of International Business Studies, 47: 881-897.

Dabić, M., Maley, J., Dana, L.-P., Novak, I., Pellegrini, M. M., et al. 2020. Pathways of SME internationalization: A bibliometric and systematic review. Small Business Economics, 55(3): 705-725.

Dymsza, W. A. 1979. Letter from the Editor-in-Chief. Journal of International Business Studies, 10(1): 7-8.

Dymsza, W. A., \& Vambery, R. G. 1977. From the Editors. Journal of International Business Studies, 8(1): 4 .

Eden, L. 2020. Whither WIR (Redux)? AIB Insights, 20(4). https://doi.org/10.46697/001c.18029.

Fainshmidt, S., Witt, M. A., Aguilera, R. V., \& Verbeke, A. 2020. The contributions of qualitative comparative analysis (QCA) to international business research. Journal of International Business Studies, 51: 455-466.

Hilmersson, M., \& Johanson, M. 2016. Speed of SME internationalization and performance. Management International Review, 56(1): 67-94.
Li, J., Ding, H., Hu, Y., \& Wan, G. 2021. Dealing with dynamic endogeneity in international business research. Journal of International Business Studies, 52: 339-362.

Lindner, T., Puck, J., \& Verbeke, A. 2020. Misconceptions about multicollinearity in international business research: Identification, consequences, and remedies. Journal of International Business Studies, 51: 283-298.

Meyer, K. E., van Witteloostuijn, A., \& Beugelsdijk, S. 2017. What's in a p? Reassessing best practices for conducting and reporting hypothesis-testing research. Journal of International Business Studies, 48: 535-551.

Mezias, J., \& Newburry, W. 2020. Letter from the Editors: Special issue on "effects of coronavirus on international business.” AIB Insights, 20(3). https://doi.org/10.46697/001c.18179.

Nielsen, B. B., Welch, C., Chidlow, A., Miller, S. R., Aguzzoli, R., et al. 2020. Fifty years of methodological trends in JIBS: Why future IB research needs more triangulation. Journal of International Business Studies, 51(9): 1478-1499.

Saukko, P. 2005. Methodologies for cultural studies: An integrative approach. In N. Denzin \& Y. Lincoln (Eds.), The Sage Handbook of Qualitative Research: 343-356,. Sage: Thousand Oaks, CA.

Steel, P., Beugelsdijk, S., \& Aguinis, H. 2021. The anatomy of an award-winning meta-analysis: Recommendations for authors, reviewers, and readers of meta-analytic reviews. Journal of International Business Studies, 52: 23-44.

Vambery, R. G. 1978. Editorial note. Journal of International Business Studies, 9(3): 6-7.

Welch, C., \& Piekkari, R. 2017. How should we (not) judge the 'quality' of qualitative research? A reassessment of current evaluative criteria in International Business. Journal of World Business, 52: 714-725.

Zellmer-Bruhn, M., Caligiuri, P., \& Thomas, D. C. 2016. From the Editors: Experimental designs in international business research. Journal of International Business Studies, 47: 399-407. 